\title{
Degradation of polyphenols (catechin and tannic acid) in the rat intestinal tract. Effect on colonic fermentation and faecal output
}

\author{
BY LAURA BRAVO', ROCIO ABIA ${ }^{2}$, MARTIN A. EASTWOOD \\ AND FULGENCIO SAURA-CALIXTO ${ }^{1 *}$ \\ ${ }^{1}$ Instituto de Nutrición y Bromatologia, CSIC-UCM, Facultad de Farmacia, Ciudad Universitaria, \\ 28040-Madrid, Spain \\ ${ }^{2}$ Gastrointestinal Unit, Department of Medicine, Western General Hospital, Edinburgh EH4 $2 \mathrm{XU}$
}

(Received 6 January 1993 -Revised 13 September 1993 - Accepted 13 October 1993)

\begin{abstract}
Low- and intermediate-molecular-weight polyphenols are usually extracted by using different solvents (e.g. water, methanol, aqueous acetone). The aim of the present work was to study the possible effects of some extractable polyphenols (EPP) on fat and protein digestibilities and on the colonic microflora. Degradability of these compounds through the intestinal tract was also studied. Catechin and tannic acid (TA) were chosen as representatives of the most common basic structures of EPP (flavonoids and gallic acid respectively). Three groups of eight male Wistar rats were given either a control diet free of EPP, or diets containing $20 \mathrm{~g} / \mathrm{kg}$ dry matter of catechin and TA. Body-weight and food intake were monitored during a 3-week experimental period. Faeces and urine were collected daily during the third experimental week. EPP and fat were determined in faeces, and $N$ in both urine and faeces. Only $3 \cdot 1$ and $4.6 \%$ of the ingested catechin and $\mathrm{TA}$ respectively were excreted in faeces, indicating that absorption and/or degradation of these EPP had occurred. HPLC analysis of the polyphenolic content of faeces showed qualitative differences between groups. A significant increase of total faecal weight as well as water, fat and $\mathrm{N}$ excretion was produced by $\mathrm{TA}$. Catechin only caused an increase in fat excretion. In vitro fermentation assays were also performed to study the effect of EPP on the colonic microflora. Both catechin and TA affected the yield of end-products of fermentation, and were also degraded during the fermentation process.
\end{abstract}

Polyphenols: Catechin: Tannic acid: Intestinal degradation: Colonic fermentation

Polyphenols (PP) are compounds widely distributed in vegetable foods (legumes, cereals, fruits) and beverages (tea, cider, wine), and are important constituents of the human diet.

PP can be found free in the cell soluble fraction, as well as bound to the cell-wall components. The natural PP arise biogenetically from the shikimate and/or the acetate pathways. Most of them are present in a conjugated form, principally with a sugar residue. Benzoic acid and flavone are the basic structures of PP, which can be divided into different groups, e.g. phenylpropanoids, flavones, flavonoids, anthocyanidins and tannins (Singleton, 1981; Harborne, 1989).

Extractable polyphenols (EPP) are low- and intermediate-molecular-weight PP that are extracted by using different solvents (e.g. water, methanol, aqueous acetone). Highmolecular-weight (over 5000) and bound PP usually remain insoluble in these solvents (Haslam, 1988; Saura-Calixto et al. 1991; Terrill et al. 1992). From a physiological point of view, it is useful to distinguish between soluble or extractable, and bound forms of PP,

* For reprints. 
because of their different metabolism and effects in the gastrointestinal tract. Bound and highly polymerized $\mathrm{PP}$ are not absorbed in the intestine, being quantitatively recovered in faeces (Singleton, 1981; Bravo et al. 1992; 1994).

EPP appear to be absorbed from the digestive tract and produce systemic effects such as elevated levels of growth hormone in plasma and reduction of metabolic utilization of absorbed amino acids (Martin-Tanguy et al. 1976; Barry et al. 1986; Ahmed et al. 1991). Absorbed phenolics are metabolized and, after conversion of the basic structure into a new form and conjugation with body natural constituents such as glucuronic acid or sulphate, are excreted in the urine and bile (Singleton, 1981). Butler et al. (1986), utilizing tannins labelled with ${ }^{125} \mathrm{I}$, found that $61 \%$ of the radioactivity was recovered in faeces, $20 \%$ in urine and the remainder in serum, liver and kidney.

On the other hand, PP are known to have depressing effects on protein digestibility due to their ability to bind and precipitate proteins (Eggum et al. 1983; Aw \& Swanson, 1985; Oh et al. 1985), and to decrease the activity of digestive enzymes (Tamir \& Alumot, 1969; Griffiths \& Moseley, 1980; Horigome et al. 1988), producing an increase in faecal $\mathrm{N}$ excretion. Although these effects are more widely attributed to high-molecular-weight condensed tannins, lower-molecular-weight PP can also bind protein and decrease the activity of digestive enzymes (Moulay et al. 1988; Hara \& Honda, 1990). The inhibition of digestive enzymes also affects the digestibility and/or absorption of other dietary constituents such as starch (Thompson \& Yoon, 1984; Björck \& Nyman, 1987) or lipids (Nyman \& Björck, 1989; Longstaff \& McNab, 1991), and their degradation products (Marzo et al. 1987; Santidrian \& Marzo, 1989).

The objective of the present work was to study the degradability of EPP through the intestinal tract, as well as their possible effect on fat and protein digestibilities and on colonic microflora. Rat experiments and in vitro fermentation assays were performed. Catechin and tannic acid (TA) were chosen as standards representing the most common basic structures of EPP (flavonoids and gallic acid structures respectively).

\section{MATERIALS AND METHODS}

In vivo experiment

The in vivo study was carried out using the rat model, which has been found to correlate with human studies (Nyman et al. 1986).

Animals. Male Wistar rats weighing approximately $60 \mathrm{~g}$ were randomly divided into three groups of eight. Animals were placed into individual metabolism cages and kept in a room at $22 \pm 1^{\circ}$, with a $12 \mathrm{~h}$ light-dark cycle. Animals were fed on different semi-synthetic diets prepared in the laboratory. Food and water were available ad lib. After $4 \mathrm{~d}$ adaptation to diet and cages, body-weight, food intake and faecal output were monitored throughout the 3-week experimental period. Urine and faeces were collected daily during the third experimental week. Urine was collected in $\mathrm{HCl}(0.06 \mathrm{~mm})$ and analysed for $\mathrm{N}$ content. Faeces were collected and weighed daily, freeze-dried, weighed again, pooled weekly and milled to a particle size of $<0.5 \mathrm{~mm}$. PP, fat and total $\mathrm{N}$ were analysed in the pooled faeces.

Diets. Diet composition is given in Table 1. A PP-free basal diet was used as a control. TA (T-0125) and catechin (C-125l) were supplied by Sigma Chemical Co., St Louis, MO, USA. Catechin is a flavan-3-ol phenolic, and TA is a hydrolysable tannin composed of glucose esterified with six to nine gallic acid units. 
Table 1. Composition of diets ( $\mathrm{g} / \mathrm{kg}$ dry matter)

\begin{tabular}{|c|c|c|c|}
\hline Ingredients & Control diet & Catechin diet & Tannic acid diet \\
\hline Casein & 144 & 144 & 144 \\
\hline DL-Methionine & 2.9 & $2 \cdot 9$ & 2.9 \\
\hline Sucrose & 96 & 96 & 96 \\
\hline Oil* & 48 & 48 & 48 \\
\hline Mineral mixture & $36 \cdot 2$ & $36 \cdot 2$ & $36 \cdot 2$ \\
\hline Vitamin mixture & 1.2 & $1 \cdot 2$ & $1 \cdot 2$ \\
\hline Wheat starch & 671.7 & $652 \cdot 5$ & $652 \cdot 5$ \\
\hline Catechin & - & $19 \cdot 2$ & - \\
\hline Tannic acid & - & - & $19 \cdot 2$ \\
\hline
\end{tabular}

* Olive and sunflower oils; $50: 50, \mathrm{v} / \mathrm{v}$.

$\uparrow$ The mineral mixture provided (g/kg diet): $\mathrm{CaCO}_{3} 10 \cdot 0, \mathrm{KHCO}_{3} 6 \cdot 1, \mathrm{NaH}_{2} \mathrm{PO}_{4} 2 \cdot 26, \mathrm{KH}_{2} \mathrm{PO}_{4} 8 \cdot 2, \mathrm{CaHPO}_{4}$ $6 \cdot 8, \mathrm{MgSO}_{4} \cdot 7 \mathrm{H}_{2} \mathrm{O} 2 \cdot 25, \mathrm{MgCO}_{3} 0.77, \mathrm{FeSO}_{4} .7 \mathrm{H}_{2} \mathrm{O} 0.199, \mathrm{MnSO}_{4} . \mathrm{H}_{2} \mathrm{O} 0 \cdot 17, \mathrm{ZnCO}_{3} 0.026, \mathrm{NaF} 0 \cdot 0002, \mathrm{KI}$ $0.0002, \mathrm{Na}_{2} \mathrm{CrO}_{4} 0.001, \mathrm{Na}_{2} \mathrm{SeO}_{3} .5 \mathrm{H}_{2} \mathrm{O} 0.0002, \mathrm{CuSO}_{4} .5 \mathrm{H}_{2} \mathrm{O} 0.025$.

\$ The vitamin mixture provided $(\mathrm{mg} / \mathrm{kg}$ diet $):$ pteroylmonoglutamic acid $1 \cdot 1 \mathrm{l}$, niacin 22.22 , calcium pantothenate $8 \cdot 88$, riboflavin $3 \cdot 33$, thiamin $4 \cdot 44$, pyridoxine $6 \cdot 66$, cyanocobalamin $0 \cdot 055$, choline $1111 \cdot 11$, retinol $8 \cdot 88$, cholecalciferol $11 \cdot 11$, menadione $0 \cdot 055$, tocopherol $33 \cdot 33$.

\section{In vitro fermentation system}

The in vitro fermentation system simulates events occurring in the large intestine, providing a useful technique for predicting biological activity of a single substrate. It has been successfully used for fermentation studies of dietary fibre, resistant starch and oligosaccharides (Adiotomre et al. 1990; Edwards et al. 1992).

In vitro fermentation of $\mathrm{PP}$ was carried out by a closed batch-culture technique under strict anaerobic conditions using $\mathrm{O}_{2}$-free $\mathrm{CO}_{2}$. The analysis of PP and short-chain fatty acids (SCFA) after fermentation provides information about the colonic degradation process. Fermentation was run in duplicate.

The medium used was based on tryptone $(2.5 \mathrm{~g} / \mathrm{l})$ and minerals $\left(\mathrm{Na}_{2} \mathrm{HPO}_{4} 1.4 \mathrm{~g} / \mathrm{l}\right.$, $\mathrm{KH}_{2} \mathrm{PO}_{4} 1.6 \mathrm{~g} / 1, \mathrm{MgSO}_{4} .4 \mathrm{H}_{2} \mathrm{O} 0.2 \mathrm{~g} / \mathrm{l},\left(\mathrm{NH}_{4}\right) \mathrm{HCO}_{3} 1 \mathrm{~g} / 1, \mathrm{NaHCO}_{3} 8.7 \mathrm{~g} / 1, \mathrm{CaCl}_{2} .2 \mathrm{H}_{2} \mathrm{O}$ $16.5 \mathrm{mg} / 1, \quad \mathrm{MnCl}_{2} .4 \mathrm{H}_{2} \mathrm{O} \quad 12.5 \mathrm{mg} / 1, \quad \mathrm{CoCl}_{2} .6 \mathrm{H}_{2} \mathrm{O} 1.25 \mathrm{mg} / 1, \mathrm{FeCl}_{3} .6 \mathrm{H}_{2} \mathrm{O} \quad 1 \mathrm{mg} / 1 ;$ Adiotomre et al. 1990). Rat caecal contents were used as inoculum.

Approximately $12 \mathrm{~g}$ fresh rat caecal contents were removed from three rats previously fed on a commercial high-fibre diet (Diet CRM(X), Labsure Ltd, Croydon, Surrey) and homogenized in sterile anaerobic medium to give $8 \mathrm{~g}$ rat caecum contents $/ 100 \mathrm{ml}$ medium. The slurry was mixed at $37^{\circ}$ for $45 \mathrm{~min}$ to break up the caecal fibre matrix, then filtered to remove large fibre particles. The filtrate was retained for inoculation.

Medium $(30 \mathrm{ml}$ ) and $1 \mathrm{ml}$ reducing solution (cysteine hydrochloride $6.2 \mathrm{~g} / 1, \mathrm{NaOH}$ $1.6 \mathrm{~g} / 1$ and $\mathrm{Na}_{2} \mathrm{~S} .9 \mathrm{H}_{2} \mathrm{O} 6.2 \mathrm{~g} / 1$ ) were dispensed into $150 \mathrm{ml}$ Medical Flat bottles. Samples were added, followed by $10 \mathrm{ml}$ inoculum. The bottles were gassed with $\mathrm{CO}_{2}$ and closed with 'suba seal' stoppers, then placed in an incubator at $37^{\circ}$ for $24 \mathrm{~h}$. A PP-free control was also prepared.

Catechin and TA were used as fermentation substrates. A portion of each substrate $(200 \mathrm{mg}$ ) was dissolved in $40 \mathrm{ml}$ medium to give a final concentration of $5 \mathrm{~g} / 1$. SCFA (acetic, propionic, butyric, isobutyric, valeric and isovaleric acids) and non-volatile carboxylic acids (NVCA; lactic, pyruvic, malonic, succinic and fumaric acids) were analysed after $24 \mathrm{~h}$ fermentation.

In order to study the metabolism of catechin and TA through the fermentation process and their possible influence on SCFA production, two different concentrations of both 
catechin and TA $(2.5 \mathrm{~g} / \mathrm{l}$ and $1 \mathrm{~g} / \mathrm{l})$ were assessed separately. The experiment was repeated in the presence of glucose $(5 \mathrm{~g} / \mathrm{l})$ as a readily fermentable substrate. After $72 \mathrm{~h}$ fermentation, portions of the solutions were removed for SCFA determination and quantitative and qualitative analysis of PP.

\section{Analytical methods}

$P P$ determination. Soluble PP were extracted from diets and faeces by shaking at room temperature once with methanol-water $(5: 5, \mathrm{v} / \mathrm{v} ; 50 \mathrm{ml} / \mathrm{g}$ sample, $60 \mathrm{~min})$ and once with acetone-water $(7: 3, \mathrm{v} / \mathrm{v} ; 50 \mathrm{ml} / \mathrm{g}$ sample, $60 \mathrm{~min})$. The extracts were combined and analysed for PP content.

PP were determined in the extracts of both diets and faeces, as well as in the portions of the fermentation solutions, by assaying with the Folin-Ciocalteau reagent and measuring absorbances at $750 \mathrm{~nm}$ (Montreau, 1972). Catechin and TA were used as standards in the analysis of the corresponding extracts. The PP determined by the Folin-Ciocalteau method represent the total content of EPP, including both flavan-3-ol and gallic acid derivatives.

Although the vanillin method is specific for flavanols and dihydrochalcones (Sarkar \& Howarth, 1976), we used the Folin-Ciocalteau procedure to determine catechin because an underestimation of the catechin content in the extract of the catechin diet was observed with the vanillin method, as has also been reported by other authors using this method in other foodstuffs (Shahkhalili et al. 1990). This underestimation was not found when the Folin-Ciocalteau reagent was used.

Chromatographic identification of PP. High-performance reversed-phase liquid chromatography was performed to identify polyphenolic compounds in the in vivo experiment. A high performance Merck-Hitachi liquid chromatograph (Darmstadt, Germany) equipped with an L-6200 pump (Intelligent Pump), L-3000 photodiode-array detector and D-6000 (Dad Manager) software was used.

Faeces were extracted with methanol-water $(7: 3, \mathrm{v} / \mathrm{v} ; 20 \mathrm{ml} / \mathrm{g}$ sample) overnight at room temperature, twice. The combined extracts were evaporated to dryness under vacuum at $37^{\circ}$ and redissolved in $1 \mathrm{ml}$ methanol. Catechin and TA standards were dissolved in methanol for HPLC analysis.

The methanolic solutions $(20 \mu \mathrm{l})$ were analysed by reversed-phase HPLC using a $5 \mu \mathrm{m}$ Lichrocart $100 \mathrm{RP}-18(100 \times 4.6 \mathrm{~mm}$ i.d. $)$ column. Formic acid-water $(5: 95, \mathrm{v} / \mathrm{v}$; solvent $\mathrm{A})$ and methanol (solvent B) were used for gradient elution. A linear gradient was applied starting from $95 \%$ solvent $\mathrm{A}$ and changing to $80 \%$ solvent $\mathrm{B}$ over $30 \mathrm{~min}$, then to $95 \%$ solvent A over $5 \mathrm{~min}$ and maintaining isocratically for $5 \mathrm{~min}$. The flow rate was $1 \mathrm{ml} / \mathrm{min}$. The effluent was monitored at $280 \mathrm{~nm}$.

TLC was used to identify the phenolic compounds in the portions of the fermentation solutions. Plates were prepared with cellulose MN 300.

TA derivatives were determined by TLC on linear cellulose plates, eluted with $60 \mathrm{ml} / 1$ aqueous acetic acid. Spots were detected by spraying with the Folin-Ciocalteau reagent followed by exposure to $\mathrm{NH}_{3}$ vapour for spot detection (Harborne, 1973). TA was used as standard.

Flavonols were identified by two-dimensional TLC, developing the chromatograms with $n$-butanol-acetic acid--water $(4: 1: 5$, by vol.; BAW) and aqueous acetic acid $(150 \mathrm{ml} / 1$; Markham, 1982). Spots were located under u.v. light and by spraying with colourdeveloping reagents ( $p$-nitroaniline, anhydrous sodium carbonate, lead acetate basic) and with $\mathrm{NH}_{3}$ vapour.

Determination of endproducts of fermentation. Portions of the fermentation solutions were taken for analysis of the endproducts of fermentation: SCFA and NVCA.

A gas chromatograph equipped with a flame ionization detector was used (Carlo-Erba 
4200 , Milan, Italy). SCFA were separated on a $2 \mathrm{~m}$ glass column of $2 \mathrm{~mm}$ i.d., packed with $10 \%$ SP $1200-1 \% \mathrm{H}_{3} \mathrm{PO}_{4}$ on 80-100 mesh Chromosorb W-AW. The injector, detector and oven temperatures were $120^{\circ}, 80^{\circ}$ and $200^{\circ}$ respectively. The temperature program was: initial temperature $120^{\circ}$, final temperature $180^{\circ}$; rate of temperature increase $15^{\circ} / \mathrm{min}$. Initial time 0 ; final time $5 \mathrm{~min}$.

SCFA were determined by a modification of the method of Spiller et al. (1980), using 4methyl- $n$-valeric acid as internal standard. NVCA were measured using procedures described by Holdeman et al. (1977), using maleic acid as standard.

Nitrogen and fat determination. Diets, urine and faeces were analysed for total $\mathrm{N}$ by the Kjeldahl method, using concentrated $\mathrm{H}_{2} \mathrm{SO}_{4}$ at $350^{\circ}$, with Se as catalyst (Tecator Kjeltec equipment, Höganäs, Sweden). Crude protein was calculated as $\mathrm{N} \times 6.25$.

Fat was determined gravimetrically in diet and faeces after extraction with light petroleum (b.p. $40-60^{\circ}$ ) with Soxhlet equipment.

\section{Statistical analysis}

Results are presented as mean values and standard errors. Data were analysed by one-way analysis of variance. The homogeneity of variances was checked using the Cochran test. In those treatments with variance heterogeneity, Student's $t$ test was used to evaluate differences between group means. The level of significance was $P<0 \cdot 05$.

\section{RESULTS}

\section{In vivo experiment}

Table 2 shows the weight gain, food intake, faecal output and water excretion during the third experimental week. No significant differences in growth rate and food intake were observed. However, a significant increase in dry matter excretion was observed with TA, while catechin caused a decrease in the stool weight. The water excretion was higher in the TA-fed group, but not in the catechin-fed group.

\section{Protein and fat excretion}

Intake and excretion of protein and fat are shown in Table 3. A significant increase in faecal $\mathrm{N}$ excretion was observed in the TA-fed animals, but not in the catechin-fed group. As a consequence of this higher $\mathrm{N}$ excretion in the TA group, the digestive and metabolic indices of protein (apparent digestibility coefficient and $\mathrm{N}$ balance) were lower in this group, although the protein efficiency ratio (weight gain per weight of protein eaten) was not affected.

A significant increase in fat excretion was observed in both the catechin and TA groups (Table 3).

\section{Degradation of EPP}

The intake and faecal excretion of catechin and TA are detailed in Table 4. Only small amounts of these compounds appeared in faeces $(3.13$ and $4.45 \%$ of the ingested catechin and $\mathrm{TA}$ respectively), suggesting a high susceptibility to intestinal degradation.

Qualitative changes in EPP after their passage through the intestine can be observed in Figs 1 and 2. Fig. $1(a)$ shows the reversed-phase HPLC chromatogram corresponding to the catechin standard used in the formulation of the diet. Fig. 1 $(b)$ corresponds to the chromatogram of the extract obtained from the faeces of the catechin-fed group. As shown, catechin was present in faeces, as well as a catechin derivative, probably an $O$-methyl derivative.

Similarly, chromatograms corresponding to the TA standard (Fig. 2(a)) and the extract of the faeces of the TA-fed group (Figure $2(b)$ ) are shown. Gallic acid (retention time $\left(\mathrm{R}_{\mathrm{t}}\right)$ 
Table 2. Effect of polyphenols on weight gain, food intake, stool weight and water content of faeces of rats*

(Mean values with their standard errors for eight rats per dietary group; df 23)

\begin{tabular}{|c|c|c|c|c|c|c|}
\hline & \multicolumn{2}{|c|}{ Control group } & \multicolumn{2}{|c|}{ Catechin group } & \multicolumn{2}{|c|}{ Tannic acid group } \\
\hline & Mean & $\mathrm{SE}$ & Mean & SE & Mean & SE \\
\hline Weight gain $(\mathrm{g} / 7 \mathrm{~d})$ & $41 \cdot 8$ & $3 \cdot 16$ & $32 \cdot 9$ & $5 \cdot 26$ & $38 \cdot 1$ & $2 \cdot 78$ \\
\hline Food intake (g DM/7d) & $98 \cdot 7$ & 3.67 & $105 \cdot 4$ & 4.95 & $103 \cdot 1$ & $3 \cdot 11$ \\
\hline Stool weight $(\mathrm{g} \mathrm{DM} / 7 \mathrm{~d})$ & $2 \cdot 8^{a}$ & 0.09 & $2 \cdot 4^{b}$ & $0 \cdot 10$ & $3 \cdot 6^{\mathrm{c}}$ & 0.17 \\
\hline Water content of faeces $(\mathrm{g} / 7 \mathrm{~d})$ & $0 \cdot 9^{\mathrm{a}}$ & 0.03 & $0 \cdot 9^{\mathrm{a}}$ & 0.03 & $1 \cdot 2^{\mathrm{b}}$ & 0.17 \\
\hline
\end{tabular}

DM, dry matter.

\&. b.e Mean values with unlike superscript letters within a row were significantly different $(P<0.05)$.

* For details of diets and procedures, see Table 1 and p. 935.

Table 3. Intake and excretion of fat and protein and protein utilization indices in rats given diets containing polyphenols*

(Mean values with their standard errors for eight rats per dietary group; df 23)

\begin{tabular}{|c|c|c|c|c|c|c|}
\hline & \multicolumn{2}{|c|}{ Control group } & \multicolumn{2}{|c|}{ Catechin group } & \multicolumn{2}{|c|}{ Tannic acid group } \\
\hline & Mean & SE & Mean & $\mathrm{SE}$ & Mean & SE \\
\hline Fat intake $(\mathrm{g} / 7 \mathrm{~d})$ & $5 \cdot 2$ & $0 \cdot 19$ & $5 \cdot 2$ & $0 \cdot 24$ & $5 \cdot 1$ & 0.17 \\
\hline Fat excretion (g/7 d) & $0.07^{\mathrm{a}}$ & 0.002 & $0 \cdot 19^{\mathrm{b}}$ & 0.010 & $0 \cdot 16^{\circ}$ & $0 \cdot 010$ \\
\hline Protein intake $(\mathrm{g} / 7 \mathrm{~d})$ & $15 \cdot 2$ & 0.57 & $15 \cdot 8$ & $0 \cdot 74$ & $15 \cdot 6$ & 0.47 \\
\hline Faecal $\mathrm{N}(\mathrm{mg} / 7 \mathrm{~d})$ & $153 \cdot 7^{\mathrm{a}}$ & $4 \cdot 86$ & $140 \cdot 2^{\mathrm{a}}$ & $5 \cdot 87$ & $270 \cdot 2^{b}$ & $12 \cdot 90$ \\
\hline Urinary $\mathrm{N}(\mathrm{mg} / 7 \mathrm{~d})$ & $661 \cdot 0$ & 6.64 & 736.8 & $8 \cdot 23$ & $647 \cdot 3$ & $8 \cdot 44$ \\
\hline ADC $(\%)$ & $93 \cdot 8^{\mathrm{a}}$ & 0.22 & $94 \cdot 5^{a}$ & 0.47 & $89 \cdot 2^{b}$ & $0 \cdot 21$ \\
\hline PER & $2 \cdot 7$ & 0.21 & $2 \cdot 1$ & $0 \cdot 26$ & $2 \cdot 4$ & 0.15 \\
\hline $\mathrm{NB}(\mathrm{g} / 7 \mathrm{~d})$ & $1 \cdot 6^{\mathrm{a}, \mathrm{b}}$ & 0.07 & $1 \cdot 7^{\mathrm{a}}$ & 0.09 & $1 \cdot 6^{b}$ & 0.06 \\
\hline
\end{tabular}

ADC, apparent digestibility coefficient of protein: (ingested - faecal) $\times$ ingested $^{-1} \times 100 ;$ PER, protein efficiency ratio: weight gain $(\mathrm{g}) \times$ protein ingestion ${ }^{-1}(\mathrm{~g}) ; \mathrm{NB}, \mathrm{N}$ balance : intake - (faecal + urinary).

a. h, c Mean values with unlike superscript letters within a row were significantly different $(P<0.05)$.

* For details of diets and procedures, see Table 1 and p. 935.

Table 4. Intake and faecal excretion of polyphenols by rats*

(Mean values with their standard errors for eight rats per dietary group; df 23)

\begin{tabular}{|c|c|c|c|c|c|c|c|c|}
\hline & \multicolumn{6}{|c|}{ Faecal excretion } & \multirow{2}{*}{\multicolumn{2}{|c|}{$\begin{array}{c}\text { Apparent } \\
\text { digestibility } \ddagger(\%)\end{array}$}} \\
\hline & \multicolumn{2}{|c|}{$\begin{array}{c}\text { Intake } \\
\mathrm{g} / 7 \mathrm{~d}\end{array}$} & \multicolumn{2}{|c|}{$\mathrm{g} / \mathrm{kg} \dagger$} & \multicolumn{2}{|c|}{$g / 7 d$} & & \\
\hline & Mean & $\mathrm{SE}$ & Mean & $\mathrm{SE}$ & Mean & $\mathrm{SE}$ & Mean & $\mathrm{SE}$ \\
\hline Catechin & $2 \cdot 1$ & 0.09 & $26 \cdot 9$ & 0.06 & 0.07 & 0.01 & $96 \cdot 9$ & 0.19 \\
\hline Tannic acid & $2 \cdot 1$ & 0.05 & 26.9 & 0.05 & $0 \cdot 10$ & 0.01 & $95 \cdot 4$ & 0.10 \\
\hline
\end{tabular}

* For details of diets and procedures, see Table 1 and p. 935.

$\uparrow$ Polyphenols analysed in the pool of faeces; mean of three determinations.

$\$$ Apparent digestibility: (ingested - excreted) $\times$ ingested $^{-1} \times 100$. 

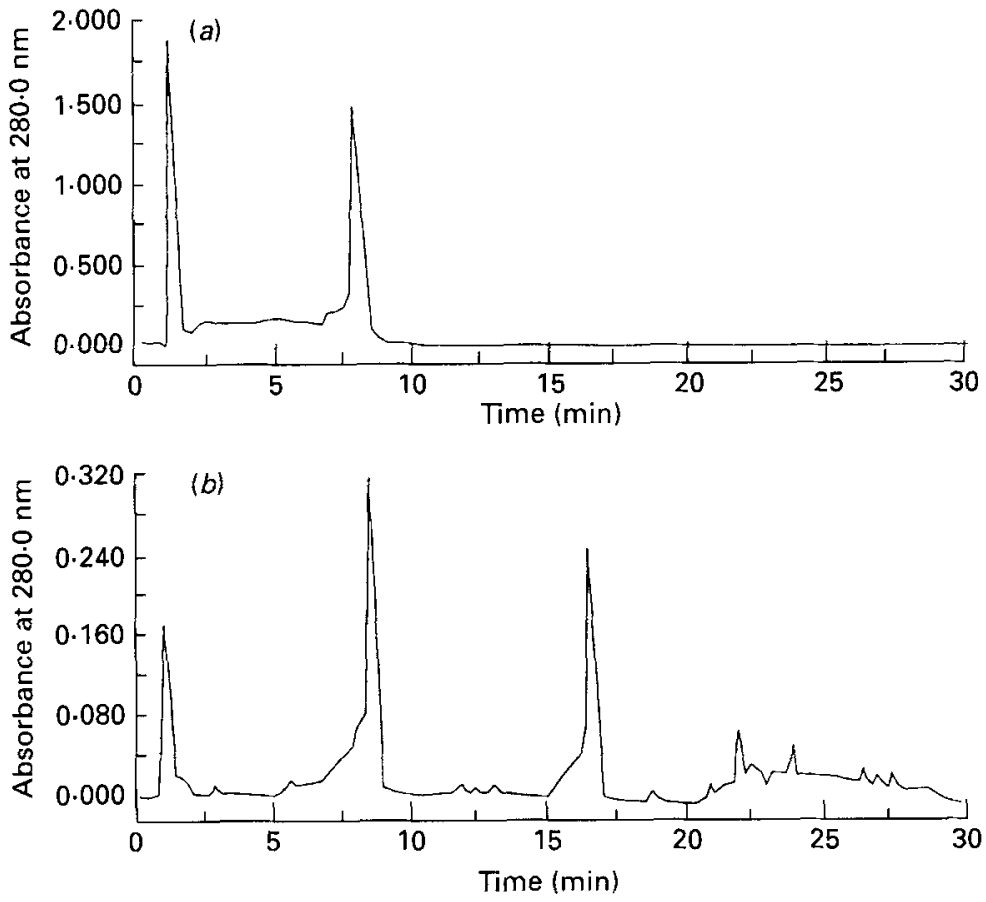

Fig. 1. (a) Reversed-phase HPLC chromatogram of the catechin standard used in the formulation of the diet.

(b) Chromatogram corresponding to the methanolic extract of the faeces of rats fed with catechin.
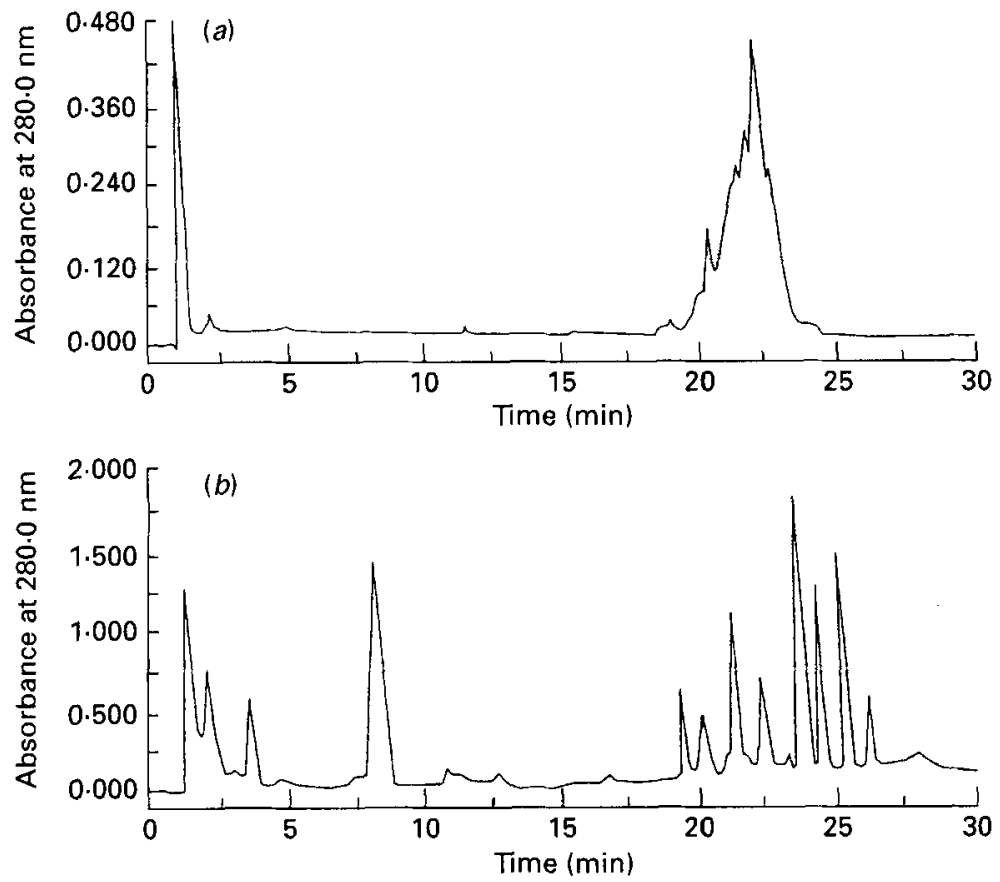

Fig. 2. (a) Reversed-phase HPLC chromatogram of the tannic acid standard used in the formulation of the diet. (b) Chromatogram corresponding to the methanolic extract of the faeces of rats fed with tannic acid. 
Table 5. Short-chain fatty acid production $(\mathrm{mmol} / \mathrm{l})$ in the presence of polyphenols after $24 \mathrm{~h}$ in vitro fermentation with a rat caecal inoculum

(Mean values with their standard errors for four determinations; df 11)

\begin{tabular}{|c|c|c|c|c|c|c|c|c|}
\hline & \multicolumn{2}{|c|}{ Acetic acid } & \multicolumn{2}{|c|}{ Propionic acid } & \multicolumn{2}{|c|}{ Butyric acid } & \multicolumn{2}{|c|}{ Total } \\
\hline & Mean & $\mathrm{SE}$ & Mean & $\mathrm{SE}$ & Mean & $\mathrm{SE}$ & Mean & $\mathrm{SE}$ \\
\hline Control & $15 \cdot 9^{\mathrm{x}}$ & $1 \cdot 12$ & $5 \cdot 0^{\mathrm{a}}$ & 0.26 & $4 \cdot 6^{\mathrm{a}}$ & $0 \cdot 28$ & $25 \cdot 8^{\mathrm{a}}$ & 0.65 \\
\hline Catechin & $14 \cdot 6^{a}$ & $0 \cdot 23$ & $5 \cdot 1^{a}$ & 0.05 & $5 \cdot 4^{\mathrm{a}}$ & $0 \cdot 10$ & $25 \cdot 2^{\mathrm{a}}$ & 0.29 \\
\hline Tannic acid & $8 \cdot 6^{\mathrm{b}}$ & $0 \cdot 31$ & $3 \cdot 1^{b}$ & $0 \cdot 04$ & $4 \cdot 0^{b}$ & $0 \cdot 18$ & $15 \cdot 7^{b}$ & $0 \cdot 18$ \\
\hline
\end{tabular}

a,b Mean values with unlike superscript letters within a column were significantly different $(P<0.05)$.

Table 6. Short-chain fatty acid production (mmol/l) after $72 \mathrm{~h}$ in vitro fermentation with a rat caecal inoculum in the presence of polyphenols

(Mean values with their standard errors for four determinations; df 11)

\begin{tabular}{|c|c|c|c|c|c|c|c|c|c|c|c|c|}
\hline & \multicolumn{6}{|c|}{ Catechin } & \multicolumn{6}{|c|}{ Tannic acid } \\
\hline & \multicolumn{2}{|c|}{ Control } & \multicolumn{2}{|c|}{$1 \mathrm{~g} / 1$} & \multicolumn{2}{|c|}{$2.5 \mathrm{~g} / \mathrm{l}$} & \multicolumn{2}{|c|}{ Control } & \multicolumn{2}{|c|}{$1 \mathrm{~g} / 1$} & \multicolumn{2}{|c|}{$2.5 \mathrm{~g} / 1$} \\
\hline & Mean & $\mathrm{SE}$ & Mean & $\mathrm{SE}$ & Mean & $\mathrm{SE}$ & Mean & $\mathrm{SE}$ & Mean & SE & Mean & $\mathrm{SE}$ \\
\hline Acetic acid & $87 \cdot 0^{\mathrm{a}}$ & 1.98 & $54 \cdot 3^{\mathrm{b}}$ & 6.07 & $45 \cdot 1^{\mathrm{b}}$ & $1 \cdot 59$ & $78 \cdot 3^{\mathrm{a}}$ & 0.64 & $29 \cdot 3^{b}$ & $0 \cdot 19$ & \multicolumn{2}{|c|}{ ND } \\
\hline Propionic acid & $4 \cdot 5^{\mathrm{a}}$ & 0.09 & $4 \cdot 9^{\mathrm{a}}$ & 0.27 & $4 \cdot 9^{a}$ & $0 \cdot 14$ & $5 \cdot 4^{\mathrm{a}}$ & $0 \cdot 15$ & $4 \cdot 7^{\mathrm{b}}$ & $0 \cdot 14$ & $4 \cdot 6^{b}$ & 0.09 \\
\hline Butyric acid & $5 \cdot 3^{a}$ & $0 \cdot 15$ & $7 \cdot 1^{\mathrm{b}}$ & 0.09 & $7 \cdot 5$ & 0.06 & $4 \cdot 7^{\mathrm{a}}$ & 0.39 & $5 \cdot 8^{\mathrm{b}}$ & $0 \cdot 30$ & $4 \cdot 9^{2, b}$ & 0.04 \\
\hline Total & $96 \cdot 8^{x}$ & 1.95 & $66 \cdot 3^{v}$ & 607 & $57 \cdot 5^{b}$ & 1.45 & $88 \cdot 4^{\mathrm{a}}$ & 0.54 & $39 \cdot 8^{b}$ & 0.50 & $9 \cdot 5^{c}$ & 0.13 \\
\hline
\end{tabular}

ND, not detected.

a, b.c Mean values corresponding to each polyphenol with unlike superscript letters within a row were significantly different $(P<0 \cdot 05)$.

$2.25)$ and gallic-acid derivatives $\left(R_{t} 3.41\right.$ and 8.37$)$ were present in faeces, along with other compounds with $R_{t}$ between 19 and 27 .

\section{Effect of polyphenols on in vitro fermentation}

The production of SCFA after in vitro fermentation is shown in Tables 5, 6 and 7. NVCA, as well as some SCFA (isobutyric, valeric and isovaleric) were not detected. Values are the means of four fermentation assays, run in duplicate.

The production of SCFA after $24 \mathrm{~h}$ fermentation in the presence of PP is shown in Table 5. The formation of these acids was suppressed by TA, but not by catechin under the described conditions.

Different concentrations of TA also caused a significant decrease in the SCFA levels, except for butyrate, after $72 \mathrm{~h}$ fermentation (Table 6). Total suppression of acetic acid production by a TA concentration of $2.5 \mathrm{~g} / 1$ was observed. Although catechin also decreased the levels of acetic acid, those of propionate and butyrate were increased.

Similarly, when glucose was added to the fermentation system a decrease in acetic acid formation was observed both with catechin and TA (Table 7). A decrease in the production of propionic and butyric acids was also observed in the presence of $2.5 \mathrm{~g} / 1 \mathrm{TA}$. With the same amount of catechin a small increase in the level of propionic acid was observed.

PP determination in the fermentation residues performed by the Folin-Ciocalteau 
Table 7. Short-chain fatty acid production (mmol/l) after $72 \mathrm{~h}$ in vitro fermentation with a rat caecal inoculum in the presence of polyphenols and glucose

(Mean values with their standard errors for four determinations; df 11)

\begin{tabular}{|c|c|c|c|c|c|c|c|c|c|c|c|c|}
\hline & \multicolumn{6}{|c|}{ Catechin } & \multicolumn{6}{|c|}{ Tannic acid } \\
\hline & \multicolumn{2}{|c|}{ Control } & \multicolumn{2}{|c|}{$1 \mathrm{~g} / 1$} & \multicolumn{2}{|c|}{$2 \cdot 5 \mathrm{~g} / 1$} & \multicolumn{2}{|c|}{ Control } & \multicolumn{2}{|c|}{$1 \mathrm{~g} / 1$} & \multicolumn{2}{|c|}{$2.5 \mathrm{~g} / 1$} \\
\hline & Mean & $\mathrm{SE}$ & Mean & $\mathrm{SE}$ & Mean & $S E$ & Mean & $\mathrm{SE}$ & Mean & $\mathrm{SE}$ & Mean & $\mathrm{SE}$ \\
\hline Acetic acid & $102 \cdot 9^{\mathrm{a}}$ & $3 \cdot 40$ & $79 \cdot 2^{\mathrm{b}}$ & $0 \cdot 29$ & $58 \cdot 1^{1:}$ & 0.56 & $83 \cdot 7^{\mathrm{a}}$ & 6.95 & $55 \cdot 0^{\mathrm{b}}$ & $4 \cdot 26$ & $10 \cdot 6^{\circ}$ & $0 \cdot 30$ \\
\hline Propionic acid & $9 \cdot 5^{\mathrm{a}}$ & 0.20 & $9 \cdot 6^{a}$ & $0 \cdot 25$ & $10 \cdot 3^{b}$ & 0.23 & $8 \cdot 9^{a}$ & 0.71 & $10 \cdot 4^{\mathrm{a}}$ & 0.55 & $4 \cdot 3^{\mathrm{b}}$ & 0.07 \\
\hline Butyric acid & $15 \cdot 9^{a}$ & 0.34 & $16 \cdot 1^{a}$ & 0.58 & $17 \cdot 0^{\mathrm{a}}$ & 0.50 & $16 \cdot 5^{\mathrm{a}}$ & 1.46 & $19 \cdot 1^{a}$ & $0 \cdot 37$ & $4 \cdot 9^{\mathrm{b}}$ & $0 \cdot 06$ \\
\hline Total & $128 \cdot 2^{\mathrm{a}}$ & 403 & $104 \cdot 9^{\mathrm{h}}$ & 1.02 & $854^{\circ}$ & 0.60 & $109 \cdot 0^{2}$ & $7 \cdot 32$ & $84.5^{\mathrm{b}}$ & $3 \cdot 49$ & $19 \cdot 8^{\circ}$ & 0.22 \\
\hline
\end{tabular}

a,b.c Mean values corresponding to each polyphenol with unlike superscript letters within a row were significantly different $(P<0.05)$.

method showed that between $40-60 \%$ and $75-95 \%$ respectively of the amounts of catechin and TA initially added were recovered after fermentation.

\section{DISCUSSION}

The assayed EPP (catechin and TA) did not affect growth rate and food intake during the 3-week experimental period. These results are in agreement with those of Moulay et al. (1988) with rats and guinea-pigs receiving $20 \mathrm{~g} / 1 \mathrm{TA}$ in drinking water for 18 and $26 \mathrm{~d}$. On the other hand, a growth retardation effect is usually reported in short-term experiments, although results for food consumption are contradictory. Thus, both enhancing (Santidrian \& Marzo, 1989) and depressing effects (Tamir \& Alumot, 1970; Shahkhalili et al. 1990) have been reported.

Catechin caused a small but significant decrease in the stool output of rats, and did not affect the water excretion. In contrast, TA caused an increase in dry matter excretion as well as in the water content of faeces. Similarly, a significant increase in faecal $N$ excretion was observed in the TA group (Table 3). This higher protein excretion may account for their higher faecal weight. TA has been reported to increase faecal weight by increasing the $\mathrm{N}$ contents of faeces (Mitjavila et al. 1977; Moulay et al. 1988; Santidrian \& Marzo, 1989).

Tannin-protein interactions are known to decrease protein digestibility by decreasing protein absorption and inhibiting digestive enzymes, thereby producing an increase in the faecal N excretion (Tamir \& Alumot, 1969; Griffiths \& Moseley, 1980; Eggum et al. 1983; Aw \& Swanson, 1985; Horigome et al. 1988). The minimum molecular weight for effective protein precipitation has been suggested to be 350 (Singleton, 1981), which would be achieved not by the monomer, but by a dimeric catechin. This may explain the lack of effect of catechin on faecal $\mathrm{N}$ excretion.

Fat excretion was significantly elevated by both catechin and TA. No effect of TA on fat excretion in the guinea-pig has been reported (Moulay et al. 1988). In fact a decrease in apparent digestibility of lipids by TA treatment has been reported (Tamir \& Alumot, 1969; Nyman \& Björck, 1989), while no effect was observed with catechin (Nyman \& Björck, 1989).

The low recovery of EPP in faeces $(3 \cdot 13 \%$ of the ingested catechin and $4.56 \%$ of the TA) indicates that these compounds are almost completely digested and/or absorbed in the intestinal tract, as their high apparent digestibility suggests (Table 4).

EPP such as catechin are known to be absorbed in the intestine and metabolized, 
undergoing oxidation of the aromatic ring and/or conjugation with glucuronic acid, sulphate and glycine (Towers, 1964; Williams, 1964; Kühnau, 1976). The conjugates are excreted in the urine or in the bile, when they pass back to the intestine. In the latter case they may undergo bacterial degradation of the heterocyclic ring to yield phenolic acids, which are readily absorbed and subsequently excreted into the urine (Griffiths, 1982).

Microbial breakdown of the conjugates reaching the intestine via the bile was confirmed when catechin conjugates were found in both urine and faeces in germ-free rats, but not in normal rats (Griffiths \& Barrow, 1972). Similarly, urinary excretion of the catechin ring metabolism products was reduced by co-administration of oral antibiotics (Griffiths, 1982), corroborating the idea that certain flavonoids are significantly metabolized by the intestinal microflora. Although enzymic extracts of animal organs are reported to break down flavanols to benzoic acids without the intervention of micro-organisms (Kühnau, 1976), the ring cleavage is mediated by colonic microflora in normal circumstances (Griffiths \& Barrow, 1972).

Like catechin, TA was excreted in faeces only in trace amounts (Table 4). We did not find any specific data in the literature concerning the absorption of TA. However, our results suggest that both catechin and TA structures are almost completely absorbed in the intestinal tract.

To check possible qualitative changes in EPP, diet and faeces were analysed by HPLC. Fig. 1 shows the chromatograms corresponding to the catechin group. As observed, catechin and a catechin derivative, probably an $O$-methyl derivative (Fig. 1(b)), were present in faeces. A $3^{\prime}-O$-methyl-catechin glucuronide was identified as the major biliary metabolite after oral administration of $(+)$ catechin (Griffiths, 1982).

The chromatographic analysis of TA is complicated because it is a mixture of four phenolic compounds (King \& Pruden, 1970). Under the assay conditions the chromatographic analysis of the TA standard failed to separate properly its different phenolic constituents (Fig. 2(a)). Nevertheless, qualitative differences can be observed in the faeces extract (Fig. 2(b)). Gallic acid $\left(\mathrm{R}_{\mathrm{t}} 2 \cdot 25\right)$ and gallic acid derivatives $\left(\mathrm{R}_{\mathrm{t}} 3.41\right.$ and 8.37), with the same spectrum as gallic acid, are present in the faeces, showing that intestinal degradation of TA had occurred. Along with these phenolics, other compounds with $R_{t}$ between 19 and 27 also appeared, probably originating from partial degradation of TA. The identification of these compounds was not possible owing to the lack of appropriate standards.

In vitro fermentation of catechin and TA was performed in an attempt to study the ability of colonic bacteria to utilize these substrates. Although in vitro systems have problems in maintaining the natural composition of microflora, they are less expensive and time consuming than animal studies. Furthermore, in vitro systems present the advantage that single, relatively pure substrates can be used. This facilitates chemical studies, avoiding interference from other components in the diet (Miller \& Wolin, 1981).

The inoculum derived from the rat caecum may contain residual fibre that could undergo fermentation, thereby yielding SCFA which may account for the SCFA production in the control. Since none of the tested PP significantly elevated the levels of SCFA when compared with the control, we suggest that these compounds do not seem to be fermentable at least in the same way (i.e. with the production of SCFA or NVCA) as other dietary constituents. In addition, TA caused a significant reduction of SCFA production after $24 \mathrm{~h}$ fermentation (Table 5), suggesting an inhibitory effect on the fermentation process.

Two different concentrations of catechin and TA $(1 \mathrm{~g} / 1$ and $2.5 \mathrm{~g} / \mathrm{l})$ were also assessed for their metabolism during the fermentation process (Table 6). As it has been suggested that bacterial growth could be retarded rather than suppressed by certain phenolic compounds (Chesson et al. 1982), fermentation was prolonged for $72 \mathrm{~h}$. Different results 
were obtained from experiments when catechin and TA were used as substrates (Table 6). Except for butyrate, TA caused significant decreases of the SCFA levels, with total suppression of acetic acid production by a TA concentration of $2.5 \mathrm{~g} / 1$. Butyric acid levels were slightly increased by a TA concentration of $1 \mathrm{~g} / \mathrm{l}$, but not by a concentration of $2.5 \mathrm{~g} / 1$.

Similarly, acetic acid levels were decreased by the two concentrations of catechin tested, although the high variability observed in the presence of $1 \mathrm{~g} / \mathrm{l}$ of this EPP does not allow us to state its effect on acetic acid production. A significant increase in the butyric acid level was also found when catechin was added to the fermentation system, whilst that of propionic acid was not affected.

It has been shown that certain phenolic acids inhibit the growth of rumen microorganisms (Chesson et al. 1982) and depress cellulose and protein digestion in vitro (Jung \& Fahey, 1981; Akin, 1982; Jung, 1985). TA has been reported to inhibit the activity of cellulase (EC 3.2.1.4) and other digestive enzymes in vitro (Griffiths \& Jones, 1977; Griffiths, 1981; Björck \& Nyman, 1987). Furthermore, TA has been shown to decrease the in vivo fermentability of hemicellulose (Barry et al. 1986), and protein and lipids (Nyman \& Björck, 1989), and a significant decrease of the facultative gut microflora in the red squirrel as a consequence of TA ingestion has also been reported (Eberly et al. 1983). In contrast, Nyman \& Björck (1989) found that catechin caused a decrease in the activity of proteolytic enzymes in vivo, but did not affect the microbial enzyme activity. A possible modification of catechin in the hind-gut which abolishes its inhibitory effect was suggested.

Our results show that a mixed culture of caecal micro-organisms is affected to different degrees by PP. Both catechin and TA diminished total SCFA levels. TA caused more extensive inhibition of SCFA production than catechin, suggesting that this compound may influence fermentation by exerting a toxic effect on the population of caecal bacteria.

In addition, the individual SCFA were affected differently by the tested phenols. Catechin yielded a significant increase in butyric acid production but decreased acetic acid levels. On the other hand, only small changes in propionic and butyric acid levels in the presence of TA were observed, whereas an important depression of acetic acid production was found. This production was totally inhibited at a concentration of $2.5 \mathrm{~g} / 1$, which seems to indicate that TA could be a specific inhibitor of the acetic-acid-producing microflora. Nevertheless, further microbiological studies are needed to establish relationships between the production of individual SCFA by bacterial populations in the presence of different dietary substrates, which are practically unknown due to the complexity of the colonic microflora.

Similar results were obtained when glucose was added to the fermentation system as a readily fermentable substrate (Table 7). Acetic acid production was always diminished by the assayed EPP, with variable effects on propionic and butyric acid levels depending on the type and concentration of the PP. This assay confirms the inhibitory effect of both catechin and TA on colonic fermentation.

The recoveries of catechin and TA in the fermentation residue also followed different patterns. The amount of catechin recovered (as a percentage of the amount initially added) varied between 40 and $60 \%$. TA was recovered at a much higher concentration (75-95\% of the initial amount in the fermentation system). Considering that less than $5 \%$ of the ingested catechin and TA were recovered in faeces in the in vivo experiment, these results suggest that absorption of a high proportion of catechin and TA derivatives takes place in the intestinal tract.

Both fermentation and absorption processes occur in the intestine, but flavanol-PP structures seem to be more affected by fermentation than gallic acid ones.

The determination of TA and catechin in the fermentation residues was carried out using 
the Folin-Ciocalteau reagent. This method is unspecific for phenolic compounds. Thus, it is possible that not only degradation but further structural modifications of these compounds occurred during fermentation. Chesson et al. (1982) and Jung \& Fahey (1983) have reported that some rumen micro-organisms may be capable of substantial metabolism of phenolic monomers in vitro, involving structural changes and resulting in low recoveries of the phenolics.

TLC analyses were performed in order to study the presence of degradation products in the fermentation residues. Portions from the fermentation performed in the presence of catechin produced faint green and light blue spots under u.v. light. These spots were different from the dark one near to the origin produced by catechin. Additional fuming of the plates with $\mathrm{NH}_{3}$ did not produce colour changes. The range of coloured spots from catechin derivatives is a likely indication that they represent phenolic compounds with structures related to flavonols.

Degradation of TA in the fermentation system was also detected by one-dimensional TLC. TA appeared as a dark spot near to the origin ( $\mathrm{Rf} 0 \cdot 15$ ), whereas fermented samples showed a dark spot at a Rf value of 0.54 , and a blue spot ( $\mathrm{Rf} 0.35$ ) immediately after spraying with the Folin-Ciocalteau reagent. This may indicate the presence of phenols with catechol or hydroquinone nuclei derived from the TA. Microbial degradation of TA has been reported (Deschamps et al. 1983; Deschamps, 1989), and the only degradation products obtained were gallic acid and traces of digallic and trigallic acids (Deschamps \& Lebeault, 1981).

\section{CONCLUSIONS}

Only small amounts of ingested catechin and TA appear in faeces with structural modifications, indicating that intestinal absorption and degradation have occurred.

Both polyphenolic compounds affect the production of SCFA from carbohydrate substrates during bacterial colonic fermentation. Catechin and TA are also degraded in this process.

TA induces an increase in total dry matter excretion, as well as in the fat, protein and water contents of faeces. Catechin only affects the fat excretion.

The authors wish to acknowledge $\mathrm{Dr}$ F. A. Tomás-Barberán for assistance in HPLC analysis. The financial support of the Spanish Comision Interministerial de Ciencia y Tecnología (Project ALI 89-0551) is acknowledged.

\section{REFERENCES}

Adiotomre, J., Eastwood, M. A., Edwards, C. A. \& Brydon, W. G. (1990). Dietary fiber: in vitro methods that anticipate nutrition and metabolic activity in humans. American Journal of Clinical Nutrition 52, 128-134.

Ahmed, A. E., Smithard, R. \& Ellis, M. (1991). Activities of enzymes of the pancreas, and the lumen and mucosa of the small intestine in growing broiler cockerels fed on tannin-containing diets. British Journal of Nutrition 65, $189-197$.

Akin, D. A. (1982). Forage cell wall degradation and p-coumaric, ferulic, and sinapic acids. Agronomy Journal 74, $424-428$.

Aw, T.-L. \& Swanson, B. G. (1985). Influence of tannin on Phaseolus vulgaris protein digestibility and quality. Journal of Food Science 50, 67-71.

Barry, T. N., Allsop, T. F. \& Redekopp, C. (1986). The role of condensed tannins in the nutritional value of Lotus pedunculatus for sheep. 5. Effects on the endocrine system and on adipose tissue metabolism. British Journal of Nutrition 56, 607-614.

Björck, I. M.\& Nyman, M. E. (1987). In vitro effects of phytic acid and polyphenols on starch digestion and fiber degradation. Journal of Food Science 52, 1588-1594.

Bravo, L., Abia, R., Goñi, I. \& Saura-Calixto, F. (1994). Possible common properties between dietary fibre constituents and polyphenols. European Journal of Clinical Nutrition (In the Press).

Bravo, L., Saura-Calixto, F. \& Goñi, I. (1992). Effects of dietary fibre and tannins from apple pulp on the composition of faeces in rats. British Journal of Nutrition 67, 463-473. 
Butler, L. G., Rogler, J. C., Mehansho, H. \& Carlson, D. M. (1986). Dietary effects of tannins. In Plant Flavonoids in Biology and Medicine: Biochemical, Pharmacological, and Structure-Activity Relationships, pp. $141-157$ [V. Cody, J. B. Harborne and E. Middleton, editors]. New York: Alan R. Liss.

Chesson, A., Stewart, C. S. \& Wallace, R. J. (1982). Influence of plant phenolic acids on growth and cellulolytic activity of rumen bacteria. Applied and Environmental Microbiology 44, 597-603.

Deschamps, A. M. (1989). Microbial degradation of tannins and related compounds. ACS. Symposium Series 399 , $559-567$.

Deschamps, A. M. \& Lebeault, J.-M. (1981). Bacterial degradation of tannins. Advances in Biotechnology 2, 639-643.

Deschamps, A. M., Otuk, G. \& Lebeault, J.-M. (1983). Production of tannase and degradation of chestnut tannin by bacteria. Journal of Fermentation Technology 61, 55-59.

Eberly, K., Mould, E. \& Duff, D. (1983). Effect of dietary tannic acid on the facultative gut microflora of the red squirrel. Proceedings of the Indiana Academy of Sciences 92, 317-322.

Edwards, C. A., Adiotomre, J. \& Eastwood, M. A. (1992). Dietary fibre: the use of in vitro and rat models to predict action on stool output in man. Journal of the Science of Food and Agriculture 59, 257-260.

Eggum, B. O., Pedersen, B. \& Jacobsen, I. (1983). The influence of dietary tea, coffee and cocoa on protein and energy utilization of soya-bean meal and barley in rats. British Journal of Nutrition 50, 197-205.

Griffiths, D. W. (1981). The polyphenolic content and enzyme inhibitory activity of testas from bean (Vicia faba) and pea (Pisum spp.) varieties. Journal of the Science of Food and Agriculture 32, 797-804.

Griffiths, D. W. \& Jones, D. I. H. (1977). Cellulase inhibition by tannins in the testa of field beans (Vicia faba). Journal of the Science of Food and Agriculture 28, 983-989.

Griffiths, D. W. \& Moseley, G. (1980). The effect of diets containing field beans of high and low polyphenolic content on the activity of digestive enzymes in the intestines of rats. Journal of the Science of Food and Agriculture 31, 255-259.

Griffiths, L. A. (1982). Mammalian metabolism of flavonoids. In The Flavonoids: Advances in Research, pp. 681-718 [J. B. Harborne and T. J. Mabry, editors]. London: Chapman and Hall.

Griffiths, L. A. \& Barrow, A. (1972). Metabolism of flavonoid compounds in germ-free rats. Biochemical Journal 130, 1161-1162.

Hara, Y. \& Honda, M. (1990). The inhibition of $\alpha$-amylase by tea polyphenols. Agricultural and Biological Chemistry 54, 1939-1945.

Harborne, J. B. (1973). Phytochemical Methods. London: Chapman and Hall.

Harborne, J. B. (1989). General procedures and measurement of total phenolics. In Methods in Plant Biochemistry. 1. Plant Phenolics, pp. 1-28 [J. B. Harborne, editor]. London: Academic Press.

Haslam, E. (1988). Twenty-second Procter Memorial Lecture. Vegetable tannins - renaissance and reappraisal. Journal of the Society of Leather Technologists and Chemists 72, 45-64.

Holdeman, L. V., Cato, E. P. \& Moore, W. E. (editors) (1977). Anaerobe Laboratory Manual. Blacksbury, Virginia: Virginia Polytechnic Institute and State University.

Horigome, T., Kumar, R. \& Okamoto, K. (1988). Effects of condensed tannins prepared from leaves of fodder plants on digestive enzymes in vitro and in the intestine of rats. British Journal of Nutrition 60, 275-285.

Jung, H. J. G. (1985). Inhibition of structural carbohydrate fermentation by forage phenolics. Journal of the Science of Food and Agriculture 36, 74-80.

Jung, H. J. G. \& Fahey, G. C. (1981). Effect of phenolic compound removal on in vitro forage digestibility. Journal of Agricultural and Food Chemistry 29, 817-820.

Jung, H. J. G. \& Fahey, G. C. (1983). Interactions among phenolic monomers and in vitro fermentation. Journal of Dairy Science 66, 1255-1263.

King, H. G. C. \& Pruden, G. (1970). Lower limits of molecular weights of compounds excluded from Sephadex G-25 eluted with aqueous acetone mixtures. Application of the results to the separation of the components of tannic acid. Journal of Chromatography 52, 285-290.

Kühnau, J. (1976). The flavonoids. A class of semi-essential food components: their role in human nutrition. World Review of Nutrition and Dietetics 24, 117-191.

Longstaff, M. A. \& McNab, J. M. (1991). The effect of concentration of tannin-rich bean hulls ( Vicia faba L.) on activities of lipase $(E C 3,1.1 .3)$ and $\alpha$-amylase $(E C 3.2 .1 .1)$ in digesta and pancreas and on the digestion of lipid and starch by young chicks. British Journal of Nutrition 66, 139-147.

Markham, K. R. (1982). Isolation and analytical techniques. In Techniques of Flavonoid Identification, pp. 15-35 [J. E. Treherne and P. H. Rubery, editors]. London: Academic Press.

Martin-Tanguy, J., Vermorel, M., Lenoble, M., Martin, C. \& Gallet, M. (1976). Sorghum tannins. Importance in nutritional nitrogen use in growing rats. Annales de Biologie Animale, Biochimie, Biophysyque 16, 879-890.

Marzo, F., Santidrian, S. \& Larralde, J. (1987). Effect of tannic acid on the intestinal absorption of D-galactose in chicks. Revista Española de Fisiología 43, 529-530.

Miller, T. L. \& Wolin, M. J. (1981). Fermentation by the human large intestine microbial community in an in vitro semicontinuous culture system. Applied and Environmental Microbiology 42, 400-407.

Mitjavila, S., Lacombe, C., Carrera, G. \& Derache, R. (1977). Tannic acid and oxidized tannic acid on the functional state of rat intestinal epithelium. Journal of Nutrition 107, 2113-2121.

Montreau, F. R. (1972). Sur le dosage des composés phénoliques totaux dans les vins par la méthode 
Folin-Ciocalteau (The content of total phenolic compounds in wines measured by the Folin-Ciocalteau method). Connaissance du Vigne et Vin 24, 397-404.

Moulay, L., Phillips, H. \& Hughes, R. E. (1988). The influence of tea and tannic acid on organ weights and faecal composition in rats and in guinea-pigs. Human Nutrition: Food Sciences and Nutrition 42F, 125-131.

Nyman, M., Asp, N.-G., Cummings, J. \& Wiggins, H. (1986). Fermentation of dietary fibre in the intestinal tract: comparison between man and rat. British Journal of Nutrition 55, 487-496.

Nyman, M. E. \& Björck, I. M. (1989). In vivo effects of phytic acid and polyphenols on the bioavailability of polysaccharides and other nutrients. Journal of Food Science 54, 1332-1335, 1363.

Oh, H. I., Hoff, J. E. \& Haff, L. A. (1985). Immobilized condensed tannins and their interaction with proteins. Journal of Food Science 50, 1652-1654.

Santidrian, S. \& Marzo, F. (1989). Effect of feeding tannic acid and kidney bean (Phaseolus vulgaris) on the intestinal absorption of D-galactose and L-leucine in chickens. Journal of the Science of Food and Agriculture 47, $435-442$.

Sarkar, S. K. \& Howarth, R. E. (1976). Specificity of the vanillin test for flavanols. Journal of Agricultural and Food Chemistry 24, 317-320.

Saura-Calixto, F., Goñi, I., Mañas, E. \& Abia, R. (1991). Klason lignin, condensed tannins and resistant protein as dietary fibre constituents: determination in grape pomaces. Food Chemistry 39, 299-309.

Shahkhalili, Y., Finot, P. A., Hurrell, R. \& Fern, E. (1990). Effects of foods rich in polyphenols on nitrogen excretion in rats. Journal of Nutrition 120, 346-352.

Singleton, V. L. (1981). Naturally occurring food toxicants: phenolic substances of plant origin common in foods. Advances in Food Research 27, 149-242.

Spiller, G. A., Chernoff, M. C., Hill, R. A., Gates, J. E., Nassar, J. J. \& Shipley, E. A. (1980). Effect of purified cellulose, pectin and a low-residue diet on fecal volatile fatty acids, transit time and fecal weight in humans. American Journal of Clinical Nutrition 33, 754-759.

Tamir, M. \& Alumot, E. (1969). Inhibition of digestive enzymes by condensed tannins from green and ripe carobs. Journal of the Science of Food and Agriculture 20, 199-202.

Tamir, M. \& Alumot, E. (1970). Carob tannins - growth depression and levels of insoluble nitrogen in the digestive tract of rats. Journal of Nutrition 100, 573-580.

Terrill, T. H., Rowa, A. M., Douglas, G. B. \& Barry, T. N. (1992). Determination of extractable and bound condensed tannin concentrations in forage plants, protein concentrate meals and cereal grains. Journal of the Science of Food and Agriculture 58, 321-329.

Thompson, L. U. \& Yoon, J. H. (1984). Starch digestibility as affected by polyphenols and phytic acid. Journal of Food Science 49, 1228-1229.

Towers, G. H. N. (1964). Metabolism of phenolics in higher plants and micro-organisms. In Biochemistry of Phenolic Compounds, pp. 249-294 [J. B. Harborne, editor]. London: Academic Press.

Williams, R. T. (1964). Metabolism of phenolics in animals. In Biochemistry of Phenolic Compounds, pp. 205-248 [J. B. Harborne, editor]. London: Academic Press. 